Abstract-The dolphinfish (Coryphaena hippurus) is of major recreational and commercial importance, and landings have increased in recent years around Puerto Rico, throughout the Caribbean Sea, and along the U.S. East Coast, yet its genetic structure among these localities is uncertain. A portion of the mitochondrial nicotinamide adenine dinucleotide (NADH) dehydrogenase subunit 1 (ND1; 1288 base pairs) gene was used at 2 spatial scales to investigate the population structure of dolphinfish. In a comparison of 183 specimens of dolphinfish between the northern and southern coasts of Puerto Rico over 4 consecutive years (2010-2013), no genetic differentiation was detected $\left(\Phi_{\mathrm{ST}}=\right.$ $-0.002, P=0.640)$. On a broader scale, patterns of genetic variation of ND1 were compared for samples collected throughout the western central Atlantic from Florida, South Carolina, North Carolina (southeastern United States; N=90); Puerto Rico (northeastern Caribbean Sea; $\mathrm{N}=183$ ); Barbados, Dominica, and Trinidad and Tobago (eastern Caribbean Sea; $\mathrm{N}=43$ ); and the central North Atlantic in the Azores Islands $(\mathrm{N}=8)$, and 199 haplotypes were identified from all of the regions combined. Analysis of all samples $(\mathrm{N}=324)$ revealed shallow genetic structure $\left(\Phi_{\mathrm{ST}}=0.009, P=0.023\right)$, but pairwise regional comparisons did not, indicating low population differentiation of dolphinfish throughout the western central Atlantic.

Manuscript submitted 26 May 2014. Manuscript accepted 28 July 2015. Fish. Bull. 113:419-429 (2015).

Online publication date: 14 August 2015. doi: 10.7755/FB.113.4.5

The views and opinions expressed or implied in this article are those of the author (or authors) and do not necessarily reflect the position of the National Marine Fisheries Service, NOAA.

\title{
Genetic structure and dispersal capabilities of dolphinfish (Coryphaena hippurus) in the western central Atlantic
}

\author{
Wessley B. Merten (contact author) 1,3 \\ Nikolaos V. Schizas' \\ Matthew T. Craig ${ }^{2}$ \\ Richard S. Appeldoorn' \\ Donald L. Hammond ${ }^{3}$ \\ Email address for contact author: wessleymerten@gmail.com \\ ${ }^{1}$ Department of Marine Sciences \\ University of Puerto Rico, Mayagüez \\ P.O. Box 9000 \\ Mayagüez, Puerto Rico 00681 \\ 2 Department of Marine Science and Environmental Studies \\ University of San Diego \\ 5998 Alcalá Park \\ San Diego, California 92110 \\ ${ }^{3}$ Cooperative Science Services LLC \\ Dolphinfish Research Program \\ 961 Anchor Road \\ Charleston, South Carolina 29412
}

The combination of tagging and genetic approaches (e.g., DNA sequencing and microsatellite analyses) has led to significant improvements in characterizing the stock and population structure of marine pelagic fishes, in interpreting biomass dynamic models, in generating stock-recruitment curves, and in conducting cohort analyses (Graves, 1998; Reiss et al., 2009). Specifically, tag and genetic data can be used to estimate regional biomass exchange and define stocks demographically; this information is useful in the stock assessment process (Waples et al., 2008). Alternatively, tag or genetic data have allowed scientists to refine assessment models and facilitate a more precise allocation of management effort. Therefore, this combination of approaches provides more realistic estimates of immigration, emigration, mortality (natural and anthropogenic), and the extent of population mixing, all of which are informative in assessment models (Hilborn and Walters, 1992).

The results of these models provide fishery managers with information necessary to adjust fishing effort, set size limits and quotas, identify seasonal hot spots and essential fish habitat (e.g., Sargassum), and protect spawning stocks to safeguard recruitment and future landings (Allendorf et al., 1987), although the applicability of management measures can vary depending on effective population size (i.e., small versus large). Nevertheless, tag and genetic data are increasingly used to manage highly migratory fish stocks because they provide better estimates of spatiotemporal population differentiation and effective population sizes (Hauser and Carvalho, 2008) 
The large population sizes and high dispersal capabilities of marine pelagic fishes (e.g., tunas, swordfishes, and jacks) are thought to contribute to low genetic differentiation among their populations (Graves and Dizon, 1989; Graves and McDowell, 2003; Theisen et al., 2008). The lack of genetic heterogeneity among regional samples in these pelagic species is believed to be an outcome of reduced genetic drift due to high gene flow among the locations sampled (Hauser and Ward, 1998). Studies with the use of various nuclear and mitochondrial DNA (mtDNA) markers of yellowfin (Thunnus albacares) and bigeye (T. obesus) tuna (Graves and Dizon, 1989), striped (Kajikia audax) and white (K. albida) marlin (Graves and McDowell, 1994, 2001), swordfish (Xiphias gladius) (Alvarado Bremer et al., 1996, 2005), and wahoo (Acanthocybium solandri) (Theisen et al., 2008) have revealed limited intraand interocean divergence. Yet, some pelagic fishes (e.g., bluefin tuna [T. thynnus]) are now recognized as distinct species in the Pacific and Atlantic (Collette et al., 2001), and others show considerable genetic divergence among ocean basins (e.g., Indo-Pacific versus eastern Pacific, or Gulf of Mexico versus Mediterranean Sea) owing to physical isolation or the existence of separate spawning areas (Graves and McDowell, 2003).

In the Atlantic, no genetic heterogeneity has been detected over widespread areas for blue marlin (Makaira nigricans) (McDowell et al., 2007), sailfish (Istiophorus platypterus) (Graves and McDowell, 2003), and wahoo (Garber et al., 2005). High rates of largescale migration and subsequent mixing may reduce the probability of small-population structure. For example, movement data for blue marlin show transatlantic, interocean (Atlantic to Indian Ocean), and Atlantic transequatorial crossings over large spatial and temporal scales, and no subpopulations have been evident (Witzell and Scott, 1990; McDowell et al., 2007). However, population subdivision has been shown between bluefin tuna populations in the Atlantic despite observed transatlantic movements between the Gulf of Mexico and Mediterranean Sea from satellite and conventional tagging data (Boustany et al., 2008). Using microsatellite and mtDNA markers, Boustany et al. (2008) detected genetic heterogeneity between those populations that was likely the result of strong natal homing to either the Gulf of Mexico or the Mediterranean Sea to reproduce.

The dolphinfish (Coryphaena hippurus) is similar to many large circumtropically distributed pelagic fish species (many thunnins, istiophorids) in that the species is abundant and has a high dispersal potential in all life stages. However, although istiophorid species have varied fecundity (Eldridge and Wares, 1974; SalcedoBojorquez and Arreguin-Sanchez, 2011) and spawning grounds (Richardson, 2008), the dolphinfish is highly fecund, spawns throughout a wide geographical range, has an early age at first maturity, and a short generation time (Palko et al., 1982; Ditty et al., 1994; Benetti et al., 1995; Oxenford, 1999). Together, these features indicate that genetic differentiation would be limited in this species, yet such differentiation has been detected at several spatial scales.

At the largest spatial scale, genetic differentiation was reported between eastern Atlantic and western Pacific dolphinfish populations, presumably because of dispersal limitations and vicariance between basins (Díaz-Jaimes et al., 2010). At the basin-wide scale, Díaz-Jaimes et al. (2010), using mtDNA nicotinamide adenine dinucleotide (NADH) dehydrogenase subunit 1 (ND1) sequences, observed genetic divergence between the western (Caribbean Sea) and eastern Atlantic (Senegal). In the Pacific, analyses of mtDNA (Díaz-Jaimes et al., 2006) and microsatellite loci (Tripp-Valdez et al., 2010) showed no population separation in the Gulf of California or eastern central Pacific. However, RochaOlivares et al. (2006) did show population separation using analyses of restriction fragment length polymorphism (RFLP) when comparing dolphinfish sampled in the eastern Pacific (Los Cabos, Mexico) and central Pacific (Hawaii).

In the past, Oxenford and Hunte (1986) inferred population subdivision in the western central Atlantic from regional differences in peak landings, growth rates, size of oocytes, maturity stage of gonads, and a limited survey of allozyme variation. Their analyses led to the hypothesis that dolphinfish exist as northern (U.S. East Coast to northern Caribbean Sea) and southern (southern Caribbean Sea to Brazil) stocks.

Around Puerto Rico, anecdotal reports from fishermen and recorded observations support the differential timing of the annual arrival of adult dolphinfish along the north (fall; October-January) and south coast (spring; January-April) (Rivera and Appeldoorn, 2000). As a result, it has long been thought that these seasonal "runs" represent different dolphinfish stocks. To examine dolphinfish stock structure around Puerto Rico, Rivera and Appeldoorn (2000) examined growth rates of dolphinfish sampled around the island to detect any significant growth differences between the northern and southern runs of dolphinfish. Within the 2 stock hypothesis advanced by Oxenford and Hunte (1986), fish around Puerto Rico are thought to belong to a northern stock and would, therefore, exhibit much slower growth rates than fish in the southern stock in Barbados. However, no growth differences were detected in fish sampled around Puerto Rico or between Puerto Rico and Barbados; Rivera and Appeldoorn (2000) suggested that stock structure and migration patterns were likely to be more complicated than postulated by Oxenford and Hunte (1986).

In this study, we investigated the genetic population structure of dolphinfish around Puerto Rico and in the western central Atlantic at 2 spatial scales, using the mtDNA ND1 gene. At the larger scale, comparisons were made from distinct regions within the western central Atlantic: 1) Puerto Rico (northeastern Caribbean Sea); 2) Florida, South Carolina, and North Carolina (southeastern United States); 3) Dominica, Barbados, and Trinidad and Tobago (eastern Caribbe- 


\section{Table 1}

Genetic diversity and summary statistics of dolphinfish (Coryphaena hippurus) based on mitochondrial nicotinamide adenine dinucleotide (NADH) dehydrogenase subunit 1 (ND1) sequences by region in the western central Atlantic. N=number of samples; $N h=$ number of haplotypes per location; $h=$ haplotype diversity; $\pi=$ nucleotide diversity; $\theta_{\mathrm{S}}=$ Watterson's theta; $F_{\mathrm{s}}=$ Fu's $F_{\mathrm{s}} ; H_{\mathrm{ri}}=$ Harpending's raggedness index; $\mathrm{SSD}=$ sum of squared differences from mismatch analysis. Bold values indicate significance at $P<0.05$. In this study, the region of the southeastern United States included North Carolina, South Carolina, and Florida; the northeastern Caribbean Sea consisted of the northern and southern shores of Puerto Rico; the eastern Caribbean Sea comprised Dominica, Barbados, and Trinidad and Tobago; and the central North Atlantic consists of the Azores Islands.

\begin{tabular}{lrrrrrrrr}
\hline Regions & $\mathrm{N}$ & $N h$ & $h$ & $\pi$ & $\theta_{\mathrm{S}}$ & $F_{\mathrm{s}}$ & $H_{\text {ri }}$ & SSD \\
\hline Southeastern United States & 90 & 59 & 0.9763 & 0.0040 & 17.75 & $\mathbf{- 2 5 . 4 6}$ & 0.010 & 0.001 \\
Northeastern Caribbean Sea & 183 & 100 & 0.9768 & 0.0035 & 19.02 & $\mathbf{- 2 5 . 4 2}$ & 0.017 & 0.050 \\
Eastern Caribbean Sea & 43 & 33 & 0.9623 & 0.0046 & 16.41 & $\mathbf{- 2 4 . 5 9}$ & 0.009 & 0.002 \\
Central North Atlantic & 8 & 7 & 0.9643 & 0.0026 & 4.24 & $\mathbf{- 2 . 8 7}$ & 0.065 & 0.017 \\
Mean & $\Sigma=324$ & $\Sigma=199$ & 0.9699 & 0.0038 & 14.35 & $\mathbf{- 1 9 . 5 8}$ & 0.025 & 0.175 \\
& & & & & & & & \\
\end{tabular}

an Sea); and 4) the Azores Islands (central North Atlantic). At the smaller scale, comparisons were made within regions (e.g., within the northeastern Caribbean Sea between the northern and southern coasts of Puerto Rico). The results from these investigations were used to examine how stock structure and stock connectivity of this species in relation to Puerto Rico are reflected in the variation of the ND1 gene around the western central Atlantic and the central North Atlantic.

\section{Materials and methods}

\section{Field sampling}

Dolphinfish were primarily sampled at various locations in the western central Atlantic (Table 1, Fig. 1). Tissue samples ( $1 \mathrm{~g}$; fin clip) were collected from landing sites, when fish at recreational fishing tournaments were weighed, or in situ with hook-and-line techniques along the northern and southern coasts of Puerto Rico from 2010 through 2013, along the southeastern United States in 2012, and from Barbados in 2014. Tissue samples were taken individually, immediately preserved in individual vials containing $>95 \%$ ethanol solution, and stored at $-20^{\circ} \mathrm{C}$ once in the laboratory. Additional samples from the Azores Islands $(\mathrm{N}=8)$ and Barbados $(\mathrm{N}=5)$ collected in 1998 were obtained from the South Carolina Department of Natural Resources; these samples included fin clips or heart tissue stored in a Sarkosyl-urea solution (1\% Sarkosyl, $6 \mathrm{M}$ urea, $100 \mathrm{mM}$ Tris at pH 6.8-7.0). The samples in Sarkosylurea solution were stored at room temperature. Additional sequence data from the southeastern United States $(N=1)$ and eastern Caribbean Sea $(N=12)$ were acquired from public databases (GenBank accession numbers: AF272054-AF272061, AF290386-AF290390, AF256056).

\section{DNA extraction, PCR amplification, and sequencing}

Total genomic DNA was extracted through the use of a DNeasy $^{1}$ kit (Qiagen Inc., Valencia, CA) according to the manufacturer's instructions. Polymerase chain reaction (PCR) was used to amplify a fragment, with 1437 base pairs (bp) of the mitochondrial genome consisting of the ND1 gene and portions of the flanking transfer RNAs (tRNAs) by using the L3324 (5'-GTCCTACGTGATCTGAGTTCAG-3") and H4716 (5-TACATGTTTGGGGTATGGGC-3') primers (Chapman ${ }^{2}$ ). After quality assessment and trimming to a common length, a 1288-bp fragment was used for all analyses containing $126 \mathrm{bp}$ of the 16S RNA upstream, the entire tRNA Leu (72 bp) and tRNA Ile (69 bp) genes, a portion of the tRNA Gln (49 bp) gene downstream, and the entire ND1 gene (972 bp). PCR amplifications in $25-\mu \mathrm{L}$ volumes were prepared with BioMix Red solution (Bioline USA Inc., Taunton, MA) according to the manufacturer's instructions with the addition of $10 \mathrm{ng}$ of DNA and $5 \mu \mathrm{M}$ of each primer. Thermal cycling consisted of an initial denaturation step for $2 \mathrm{~min}$ at $94^{\circ} \mathrm{C}$, followed by 35 cycles of $94^{\circ} \mathrm{C}$ for $30 \mathrm{~s}, 53^{\circ} \mathrm{C}$ for $25 \mathrm{~s}$, and $72^{\circ} \mathrm{C}$ for $45 \mathrm{~s}$, with a final $10 \mathrm{~min}$ extension at $72^{\circ} \mathrm{C}$. Sanger sequencing in both forward and reverse directions was performed by the High Throughput Genomics Center in Seattle, Washington. All sequences and final alignment have been submitted to GenBank (accession numbers: KP057921-KP058244).

\section{Data analysis}

For visualization, quality assessment, contig (contiguous) assembly, and editing, DNA trace files were im-

\footnotetext{
${ }^{1}$ Mention of trade names or commercial companies is for identification purposes only and does not imply endorsement by the National Marine Fisheries Service, NOAA

2 Chapman, R. 2012. Personal commun. Hollings Marine Lab, Charleston, SC 29412.
} 


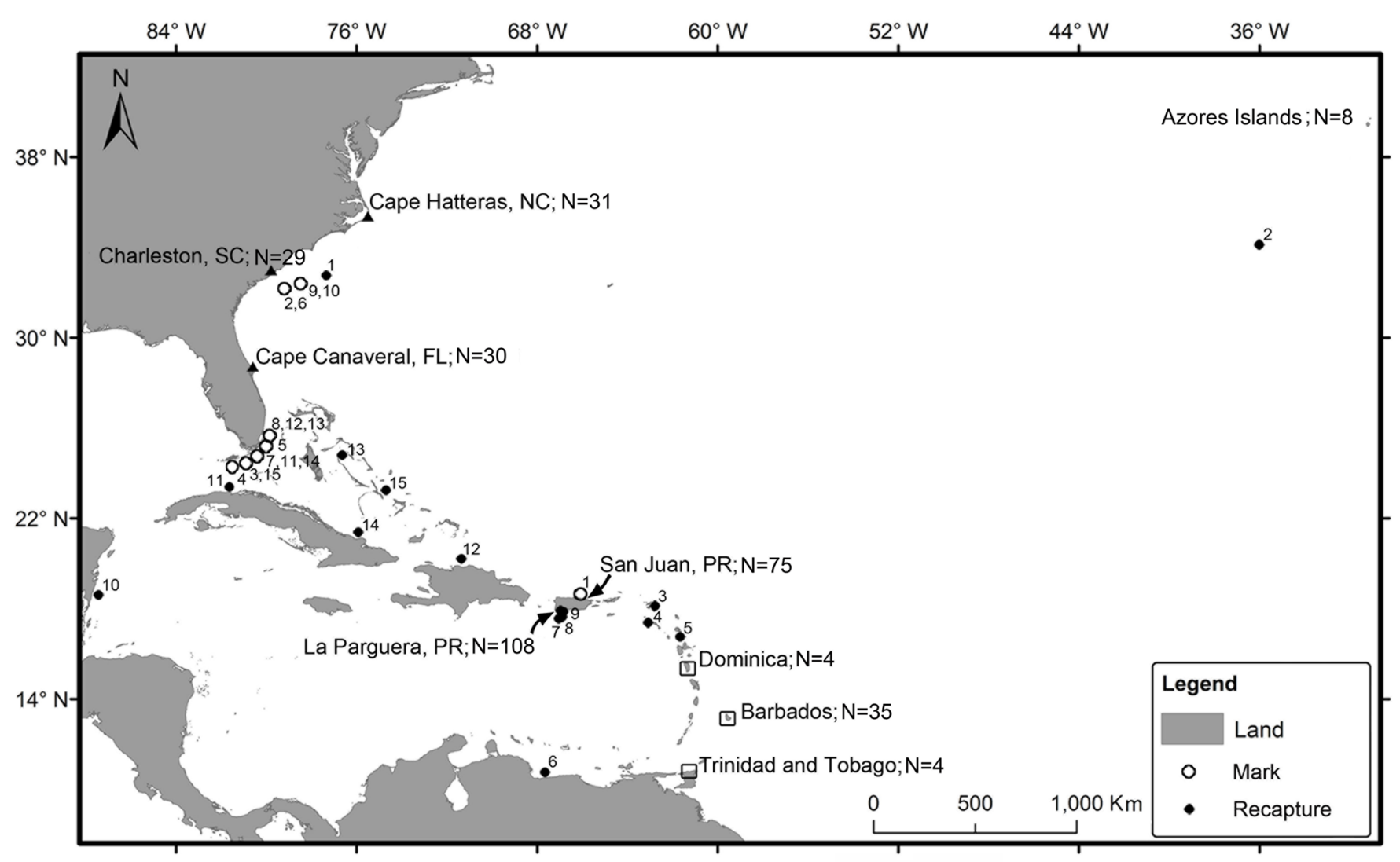

Figure 1

Tissue sample distribution and conventional tagging movements of dolphinfish (Coryphaena hippurus) in the western central and central North Atlantic. Tissue samples were taken from fish collected at different landing sites in each of the 3 regions in the western central Atlantic, including the southeastern United States in 2012 (triangles), northeastern Caribbean Sea during 2010-2013 (arrows), and eastern Caribbean Sea (open squares) during 1998 and 2014; samples from fish collected in the central North Atlantic (Azores Islands) were taken in 1998. The numbers adjacent to open circles (fish release locations) and closed circles (fish recapture locations) correspond to the tagging information in Table 4.

ported to CodonCode Aligner, vers.4.2.5 (CodonCode Corp., Centerville, MA). Sequences were aligned and trimmed to a common length with Mesquite, vers. 2.75 (Maddison and Maddison, 2011). Haplotype $(h)$ and nucleotide diversity $(\pi)$ were calculated with Arlequin, (vers. 3.5; Excoffier and Lischer, 2010). Population differentiation and the geographical pattern of variation were examined with hierarchical analyses of molecular variance (AMOVA) (Excoffier and Lischer, 2010) and pairwise comparisons of $\Phi_{\mathrm{ST}}$ through the use of the Tamura-Nei model (Tamura and Nei, 1993). Significance of $\Phi$-statistics was assessed by 10,000 permutations of groups and haplotypes. A gamma distribution parameter of $\alpha=0.881$ was used to run AMOVA. This parameter was selected by prior sequence comparisons in jModelTest, vers. 2.1.3, after the GTR+I+G DNA substitution model was selected as the best-fit model on the basis of the Akaike information criterion (Posada, 2008; Darriba et al., 2012).

Fu's $F_{\mathrm{S}}(\mathrm{Fu}, 1997)$ was used to test for deviation from the neutral model of molecular evolution (Kimura, 1968). The demographic parameters $\tau, \theta_{0}$, and $\theta_{1}$ were estimated from pairwise sequence distribution of mismatches according to the demographic and spatial expansion models. The translation of demographic parameters to estimates of effective population size were obtained by following Bowen et al. (2006). To evaluate a null hypothesis of a population expansion, Harpending's raggedness index was calculated; failure to reject the null hypothesis (i.e., nonsignificant raggedness values) indicates that there is no support for a stable (nonexpanding) population (Rogers and Harpending, 1992). Additional demographic and spatial expansion parameters, including time since expansion in years $(T)$, effective female population size $(\mathrm{Ne})$, and immigration rate from neighboring demes $(m)$, were generated according to the method of Díaz-Jaimes et al. (2006, 2010), using a maximum generation time of 3 years for dolphinfish (Mahon and Oxenford, 1999) and a mutation rate of $1.2 \%$ per million years for marine teleosts (Bermingham et al., 1997).

To test for differences in genetic structure between seasonal runs thought to occur around Puerto Rico, pairwise $\Phi_{\text {ST }}$ comparisons of samples taken from the 


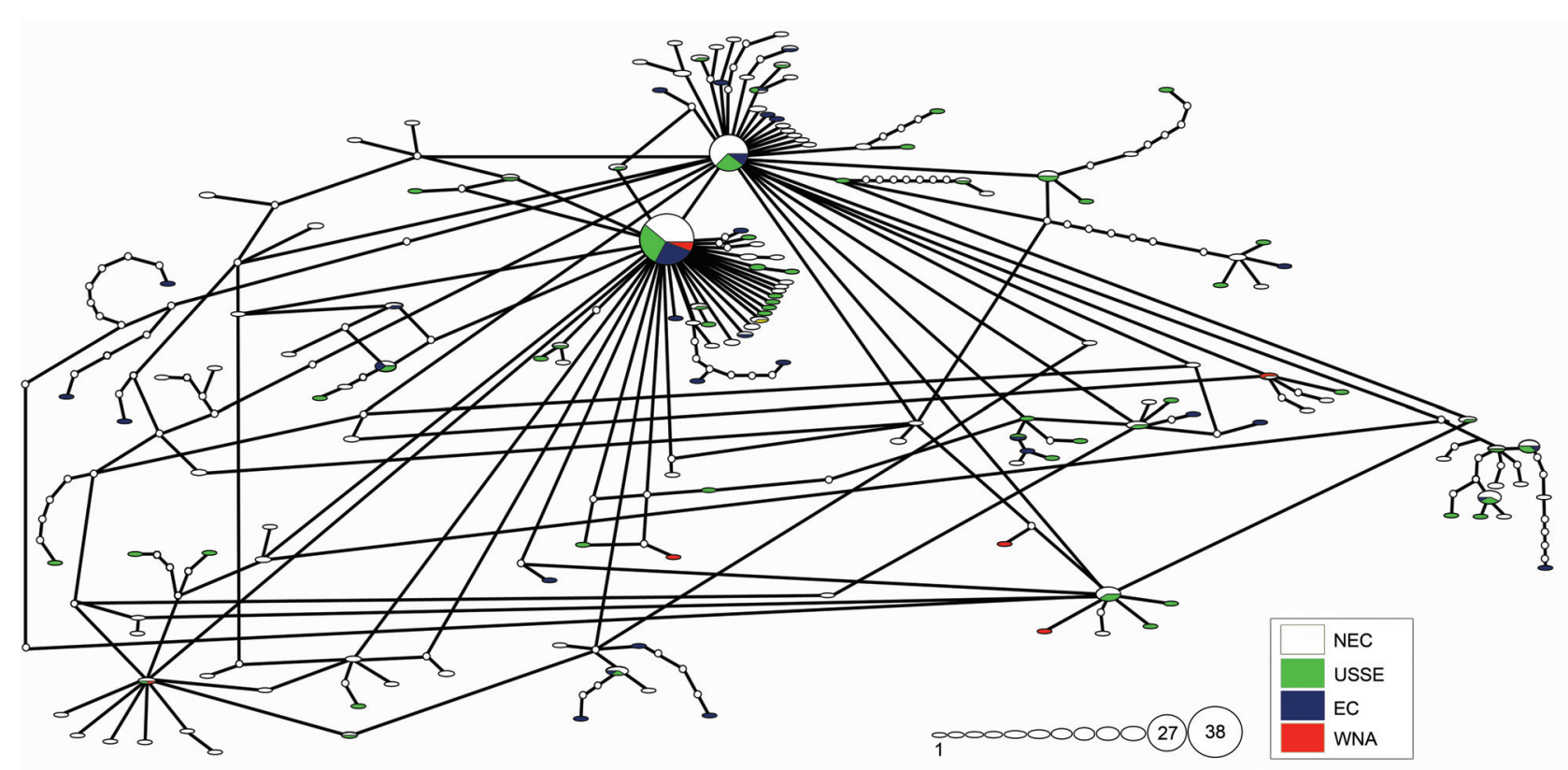

Figure 2

Statistical parsimony network for dolphinfish (Coryphaena hippurus) based on mitochondrial nicotinamide adenine dinucleotide (NADH) dehydrogenase subunit 1 (ND1) sequences. The size of circles is proportional to the number of shared haplotypes represented as pie charts. The small white circles on the connecting lines indicate the number of mutations among haplotypes and internal nodes. The color of a section in pie charts indicates a region: northeastern Caribbean Sea (NEC); southeastern United States (USSE); eastern Caribbean Sea (EC); central North Atlantic (CNA). The circles next to the legend indicate the proportionality of the number of haplotypes to the size of the circles $(1-10,27$, and 38$)$.

northern and southern coasts were compared over 4 consecutive years (2010-2013). All samples were then compared with samples collected from the southeastern United States during 2012, from the eastern Caribbean Sea during 1998 and 2014, and from the central North Atlantic during 1998. Lastly, a statistical parsimony network was generated for all haplotypes with TCS, vers. 1.2.1 (Clement et al., 2000) and redrawn in Adobe Photoshop CS5.

\section{Results}

From 324 specimens of dolphinfish collected primarily around the western central Atlantic, 199 haplotypes of a 1288-bp fragment containing ND1 and its adjacent tRNAs were resolved (Fig. 1). The haplotype network was characterized by a high number of singletons (Fig. $2)$. The most numerically dominant haplotype $(\mathrm{N}=38)$ was found in all sampling locations and mean $h$ was high (0.9699), ranging from 0.9623 in the eastern Caribbean Sea to 0.9768 in the northeastern Caribbean Sea (Table 1).

\section{Population structure}

Significant overall population differentiation ( $\left.\Phi_{\mathrm{ST}}=0.009, P=0.023\right)$ was revealed through AMOVA of all samples, but AMOVA did not reveal differentiation among areas within regions (i.e., between northern and southern Puerto Rico within the northeastern Caribbean Sea, among North Carolina, South Carolina, and Florida within the southeastern United States, or among Barbados, Dominica, and Trinidad and Tobago within the eastern Caribbean Sea) $\left(\Phi_{\mathrm{SC}}=0.014\right.$, $P=0.059)$ and among regions (i.e., northeastern Caribbean Sea versus southeastern United States versus eastern Caribbean Sea) $\left(\Phi_{\mathrm{CT}}=-0.005, P=0.301\right)$ (Table 2). Pairwise comparisons among regions failed to reveal significant differences. In addition, pairwise comparisons between the northern and southern coasts of Puerto Rico did not reveal significant differences $\left(\Phi_{\mathrm{ST}}=\right.$ $-0.002, P=0.640)$.

\section{Population expansion}

For all regions, Fu's $F_{\mathrm{S}}$ showed significant $(P<0.05)$ negative departures from neutrality and supported the spatial-population-expansion model (Table 1, Fig. 3). In addition, nonsignificant raggedness values supported the spatial-population-expansion model (Table 1). Estimates of $\tau$ (time in generations) were similar among all regions and compatible with the timing of recent population expansion beginning around 80,500 years ago (Table 3). For the southeastern United States, northeastern Caribbean Sea, and the Azores Islands, there 


\section{Table 2}

Analysis of molecular variance (AMOVA) of dolphinfish (Coryphaena hippurus) based on mitochondrial nicotinamide adenine dinucleotide (NADH) dehydrogenase subunit 1 (ND1) sequences by region in the western central Atlantic. Total population differentiation was estimated by using maximum likelihood DNA sequence pairwise distances (Tamura-Nei correction). The fixation indices for differentiation within a population among samples $\left(\Phi_{\mathrm{ST}}=0.009, P=0.023\right)$, among regions $\left(\Phi_{\mathrm{CT}}\right)$, and among areas within regions $\left(\Phi_{\mathrm{SC}}\right)$ are presented. The areas and regions in this study were the northern and southern coasts of Puerto Rico in the northeastern Caribbean Sea; Florida, South Carolina, and North Carolina within the southeastern United States; Dominica, Barbados, and Trinidad and Tobago in the eastern Caribbean Sea; and the Azores Islands in the central North Atlantic.

\begin{tabular}{lrrrr}
\hline Source of variation & Sum of squares & Variance & Variation $(\%)$ & Fixation indices \\
\hline Among regions & 8.179 & -0.1354 & -0.55 & $\Phi_{\mathrm{CT}}=-0.005(P=0.301)$ \\
Among areas within regions & 17.997 & 0.3509 & 1.41 & $\Phi_{\mathrm{SC}}=0.014(P=0.059)$ \\
Within areas & 775.105 & 2.4607 & 99.13 & \\
Total & 801.281 & 2.4822 & & \\
& & & &
\end{tabular}

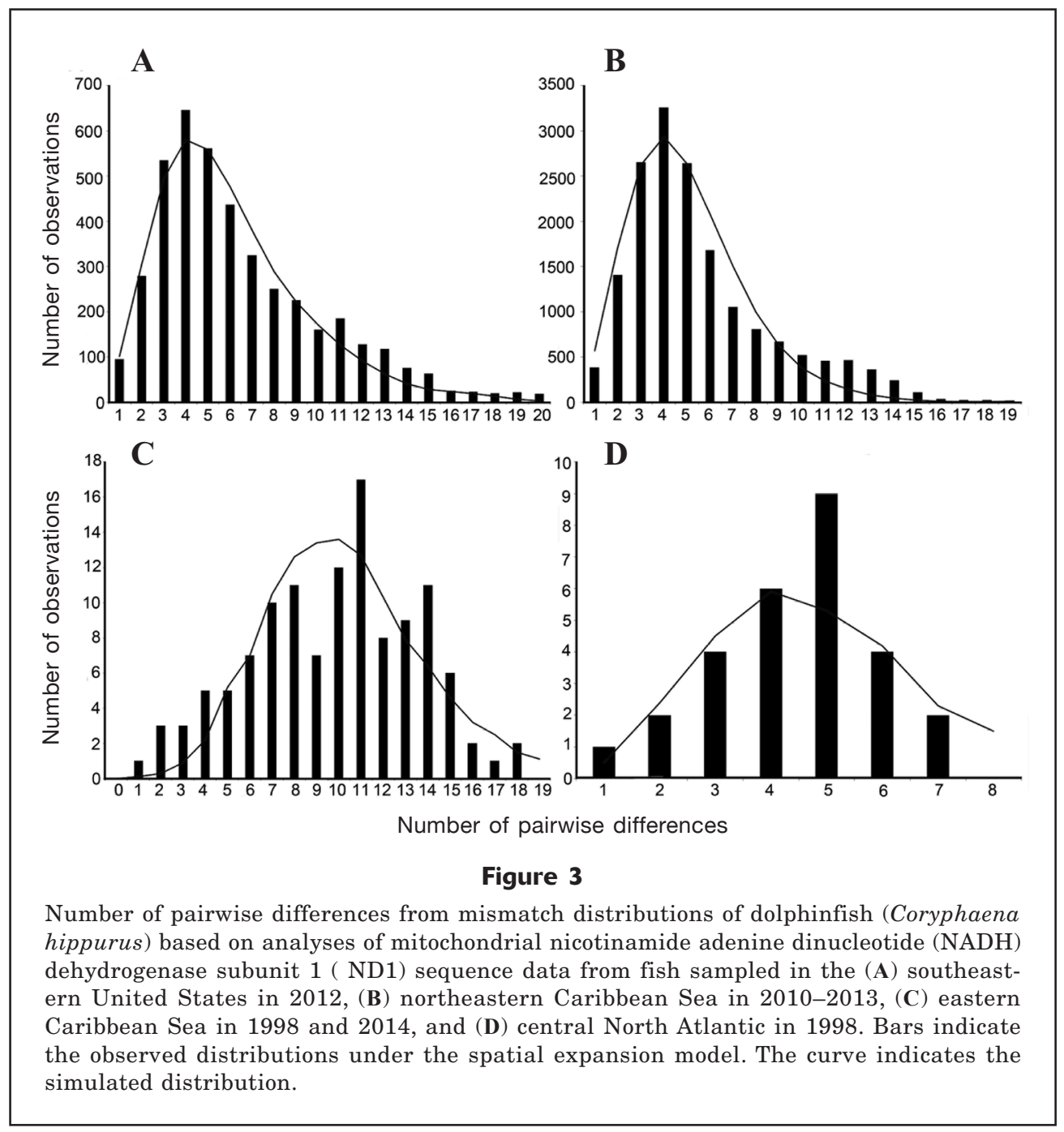




\section{Table 3}

Mismatch parameters used in the estimation of population expansion of dolphinfish (Coryphaena hippurus) based on mitochondrial nicotinamide adenine dinucleotide (NADH) dehydrogenase subunit 1 (ND1) sequence data analyzed in this study. $\tau=$ coalescence time in generations $(\tau=2 \mu T) ; \mu=$ mutation rate $1.2 \%$ per million years; $T=$ years since expansion; $\theta=$ value used to estimate initial effective population size $\left(N_{0}\right)$ before and after $\left(\theta_{1}\right)$ expansion; $N_{1}=$ population size after expansion; $M=$ scaled migration rate; $m=$ immigration rate from adjacent population; $P_{\mathrm{SSD}}=$ probability of the expected mismatch distribution to fit the expansion model. The bold value is significant at $P<0.001$. Modified following Díaz-Jaimes et al. (2010). USSE=southeastern United States; NEC=northeastern Caribbean Sea; EC=eastern Caribbean Sea; CNA=central North Atlantic.

\begin{tabular}{|c|c|c|c|c|c|c|c|c|c|c|c|c|c|c|}
\hline \multirow[t]{2}{*}{ Region } & \multicolumn{6}{|c|}{ Demographic expansion parameters } & \multirow[b]{2}{*}{$P_{\mathrm{SSD}}$} & \multicolumn{6}{|c|}{ Spatial expansion parameters } & \multirow[b]{2}{*}{$P_{\mathrm{SSD}}$} \\
\hline & $\tau$ & $T$ & $\theta$ & $N_{0}$ & $\theta_{1}$ & $N_{1}$ & & $\tau$ & $T$ & $\theta$ & $N$ & $M$ & $m$ & \\
\hline USSE & 2.21 & 71,400 & 0.00 & 0.00 & 99,999 & $2.1 \times 10^{9}$ & $>0.001$ & 2.21 & 71,400 & 2.97 & 64,000 & 99,999 & 0.78 & 0.760 \\
\hline NEC & 2.31 & 74,700 & 1.89 & 40,700 & 99,999 & $2.1 \times 10^{9}$ & 0.370 & 2.31 & 74,700 & 1.89 & 40,900 & 99,999 & 1.22 & 0.280 \\
\hline $\mathrm{EC}$ & 1.59 & 51,400 & 5.25 & 113,200 & 1205 & $2.5 \times 10^{7}$ & 0.800 & 1.61 & 52,000 & 5.23 & 112,700 & 298.00 & 0.0013 & 0.810 \\
\hline CNA & 3.85 & 124,500 & 0.00 & 0.00 & 99,999 & $2.1 \times 10^{9}$ & 0.590 & 3.85 & 124,500 & 0.007 & 15.1 & 99,999 & 3311 & 0.530 \\
\hline Mean & 2.49 & 80,500 & 1.78 & 38,475 & 75,300 & $1.6 \times 10^{9}$ & 0.440 & 2.50 & 80,650 & 2.52 & 54,353 & 75,073 & 828.25 & 0.595 \\
\hline
\end{tabular}

were large differences in $\theta_{0}$ (twice the product of the effective population size $\left[N_{0}\right]$ and mutation rate $[\mu]$ ) and in $\theta_{1}\left(2\left(\mathrm{~N}_{1} * \mu\right)\right)$, indicating rapid demographic expansions. The average value of $\theta_{0}$ among regions (1.78) indicated a small initial size for the female breeding population $\left(N_{0} \sim 38,475\right)$ followed by very rapid population expansion $\left(N_{1}=\sim 1.6 \times 10^{9}\right)$.

\section{Discussion}

Analyses of the ND1 gene in dolphinfish revealed genetic homogeneity around Puerto Rico and shallow genetic heterogeneity across the western central Atlantic but failed to identify regional genetic differences among the southeastern United States, northeastern Caribbean Sea, eastern Caribbean Sea, and central North Atlantic. These results, when examined with tag data (Fig. 1), indicate that substantial mixing is occurring throughout the western central Atlantic and that the entire region could be identified as a single stock. It is clear that migration across the region is high and the degree of reproductive isolation is low. However, although migration and reproductive isolation are critical attributes considered for stock identification, biological data sources (e.g., catch data, growth rates, fecundity at age) should be considered in future studies to strengthen the support for or against the identification of individual dolphinfish stocks in the Atlantic (Begg and Waldman, 1999).

Haplotypes were randomly distributed (Fig. 2)—a finding that indicates the presence of a single panmictic population. A possible explanation for this panmixis is Gulf Stream intensification (Coëtlogon et al., 2006) and the recirculation tendency of surface waters around the North Atlantic subtropical gyre (Richardson, 1993). This current pattern may facilitate significant migration of dolphinfish among locations in the
North Atlantic by larval dispersal and as a result of the propensity of juvenile and subadult fish to exhibit strong fidelity with floating objects (e.g., Sargassum and flotsum) (Farrell et al., 2014; Merten et al., 2014a)

The dispersal capability of large pelagic species like dolphinfish is high in the absence of obvious barriers (e.g., temperature and land). Presumably, the highly migratory nature of dolphinfish, coupled with widespread spawning activity, resulted in the moderate levels of gene flow and low genetic differentiation found in this study. This pattern is characteristic of intrabasin distributions of other pelagic fishes, including blue marlin (McDowell et al., 2007), sailfish (Graves and McDowell, 2003), and wahoo (Theisen et al., 2008). However, oceanographic features, such as gyres, or population isolation due to coastal geomorphology, could limit population mixing and lead to genetic heterogeneity. In the case of bluefin tuna, Carlsson et al. (2006) observed a slight genetic separation of stocks in the Atlantic Ocean, likely a result of geographically separated spawning areas due to coastal geomorphology, and suggested the population consists of a mixed-stock fishery.

The potential for year-round spawning behavior and the lack of reproductive isolation in dolphinfish are important life-history characteristics that contribute to the observed genetic homogeneity. Dolphinfish have been characterized as batch spawners because of the presence of several size classes of eggs in the ovaries occurring simultaneously at geographically separate regions (Palko et al., 1982; Ditty et al., 1994; Oxenford, 1999), a reproductive characteristic that indicates that females spawn over broad times and locations as they migrate throughout the region. Female dolphinfish often are active reproductively from November through July in the Straits of Florida and from May through July off Cape Hatteras, North Carolina (Palko et al., 


\section{Table 4}

Conventional mark and recapture movements of dolphinfish (Coryphaena hippurus) reported from recreational and commercial fishermen participating in the Dolphinfish Research Program in the western and central North Atlantic and Caribbean Sea from 2004-2012. DAL=days at liberty.

\begin{tabular}{|c|c|c|c|c|c|c|c|}
\hline Tag (no.) & Date tagged & Date recaptured & DAL & $\begin{array}{l}\text { Distance } \\
\quad(\mathrm{km})^{a}\end{array}$ & $\begin{array}{l}\text { Speed } \\
(\mathrm{km} / \mathrm{d})\end{array}$ & $\begin{array}{c}\text { Nearest } \\
\text { locality to } \\
\text { tagging location }\end{array}$ & $\begin{array}{c}\text { Nearest } \\
\text { locality to } \\
\text { recapture location }\end{array}$ \\
\hline 1 & 8-Nov-2011 & 30-May-2012 & 203 & 1916.22 & 9.43 & San Juan, PR & Charleston, SC \\
\hline 2 & 15-Мay-2004 & 11-Feb-2005 & 240 & 4002.77 & 17.94 & Charleston, SC & Azores Islands \\
\hline 3 & 20-Jun-2011 & 2-Mar-2012 & 256 & 2049.59 & 8.00 & Marathon, FL & St. Barthélemy \\
\hline 4 & 10-Jun-2008 & 17-May-2009 & 341 & 2058.68 & 6.03 & Big Pine Key, FL & St. Kitts \\
\hline 5 & 19-Jun-2004 & $4-F e b-2005$ & 230 & 2109.22 & 9.17 & Biscayne, FL & Antigua \\
\hline 6 & 8-Jun-2007 & 26-Feb-2008 & 263 & 2651.57 & 10.08 & Charleston, SC & Puerto Columbia, Venezuela \\
\hline 7 & 23-Jul-2004 & 26-Mar-2005 & 246 & 1610.13 & 6.54 & Islamorada, FL & Guanica, Puerto Rico \\
\hline 8 & 1-Jun-2011 & 9-Dec-2012 & 557 & 1613.39 & 2.89 & Miami, FL & Guanica, Puerto Rico \\
\hline 9 & 7-Aug-2009 & 26-Mar-2010 & 231 & 1975.73 & 8.55 & Charleston, SC & Guanica, Puerto Rico \\
\hline 10 & 15-May-2004 & 11-Feb-2005 & 330 & 1711.23 & 5.18 & Charleston, SC & Costa Maya, Mexico \\
\hline 11 & 1-Aug-2007 & 18-Mar-2008 & 230 & 198.47 & 0.86 & Islamorada, FL & Playa Escondido, Cuba \\
\hline $12^{b}$ & 2-Jun-2010 & 12-Dec-2010 & 192 & 1140.57 & 5.94 & Miami, FL & Puerto Plata, DR \\
\hline $13^{b}$ & 14-Jul-2011 & 22-Feb-2012 & 223 & 342.56 & 1.53 & Miami, FL & Exuma Sound, Bahamas \\
\hline $14^{b}$ & 24-Jul-2004 & 2-Apr-2005 & 252 & 598.91 & 2.37 & Islamorada, FL & Playa Blanca, Cuba \\
\hline $15^{\mathrm{b}}$ & 10-Jun-2009 & 24-Apr-2010 & 318 & 657.21 & 2.06 & Big Pine Key, FL & Long Island, Bahamas \\
\hline
\end{tabular}

${ }^{a}$ Minimum straight-line distance.

${ }^{b}$ Previously published data taken with permission from Merten et al. (2014b).

1982). However, larvae and early juveniles have been collected year-round off the southeastern United States and in the Caribbean Sea (Rose and Hassler, 1968; Ditty et al., 1994).

Length-frequency distributions based on data collected around the region indicate the seasonal arrival and departure of different cohorts (Rivera and Appeldoorn, 2000), again indicating multiple spawning events. However, the seasonal arrival of different cohorts may also result from schooling behavior and swimming speeds of similar-size fish or from the seasonal dynamics of the "delivery system" (e.g., cycling of Sargassum mats, which serve as a mobile habitat that constantly supports recruitment); the cycling of Sargassum may be more of an influence than reproductive timing on dolphinfish population dynamics, especially off Puerto Rico (Rivera and Appeldoorn, 2000).

Movements of dolphinfish found by conventional mark and recapture methods linked most sampled regions and provide a basis for regional connectivity and population mixing (Table 4; Fig. 1). Along the U.S. East Coast, dolphinfish move north (Merten et al., 2014a) and appear to make circuits around the Sargasso Sea and multiple movements from Florida to the Bahamas, Dominican Republic, and Cuba (Merten et al., 2014b). Movements to the Caribbean Sea are likely extensions of these shorter circuits, determined by how far north dolphinfish exit from waters of the U.S. East Coast. Exiting north of Little Bahama Bank will result in shorter migratory routes around the western central Atlantic than staying with the Gulf Stream and exiting off the Mid-Atlantic Bight. The former would result in a more direct route to the Bahamas, but the latter would likely result in eventual movement toward the northeastern Caribbean Sea. Together, the low genetic structure and the evidence of high dispersal capabilities of this species support recognition of a single stock (both fishery and genetic) throughout the western central Atlantic, with exchange between the central North Atlantic on the basis of sequence data and observed movement to the Azores Islands (Table 4, Fig. 1).

A population is composed of individuals that co-occur in space and time and interbreed, and a stock is a subgroup of the main population, capable of interbreeding, but differs in some way from the main population (i.e., timing of migration, percent occurrence by location, or growth rates) (Waples et al., 2008). Here, the high potential for long-distance migration indicated by the tagging data and the low reproductive isolation indicated by the genetic analyses of dolphinfish sampled in the western central Atlantic do not support the identification of 2 stocks as proposed by Oxenford and Hunte (1986). However, the number of samples was low from the eastern Caribbean Sea $(\mathrm{N}=43)$ and the central North Atlantic $(\mathrm{N}=8)$, and those low numbers of samples represent a major constraint in this study. With only 8 samples from the central North Atlantic, it is unlikely that genetic structure would be detected with any type of genetic marker. Additionally, the number of tagged fish showing movement between the eastern 
Caribbean Sea and other areas was small, and their movements were largely unidirectional.

In this study, genes adjacent to the coding region were incorporated into genetic analyses to add sensitivity to DNA sequence comparisons. The use of the entire ND1 gene was considered appropriate to preliminarily describe the genetic structure of dolphinfish in the western central Atlantic at different spatial scales. It is important to note that, from the onset of this study, the choice to use the ND1 marker may have influenced the outcome of results. Therefore, faster-evolving nuclear markers (e.g., microsatellites or single-nucleotide polymorphisms) may have been more suitable to detect genetic differences of dolphinfish at the scale of this study.

More samples $(\mathrm{N}>50)$ should be compared in future studies, the sampling area should be expanded to Brazil and west Africa, and more sensitive markers should be used to address the multistock question for dolphinfish across the broader Atlantic. More extensive tagging studies need to be conducted in poorly sampled areas, such as the eastern Caribbean Sea and the Azores Islands. Using more sensitive techniques, Díaz-Jaimes et al. (2010) detected low genetic structure between the Caribbean Sea and Senegal, west Africa, and suggested that isolation of dolphinfish in the Mediterranean Sea caused genetic differentiation between populations in the Mediterranean and western North Atlantic. They concluded that alternative markers should be used to define stock structure at the within-ocean level. In the eastern Pacific, Rocha-Olivares et al. (2006) observed significant genetic heterogeneity, using RFLP analyses of dolphinfish between Hawaii and Baja California (straight-line distance $=\sim 4660 \mathrm{~km}$ ); this observation was likely the result of lower gene flow among these locations but merits future investigation with more powerful molecular markers (e.g., microsatellites or singlenucleotide polymorphisms). In the Caribbean Sea and Atlantic, the spatial scale of our study (Miami, Florida, to the Azores Islands $=\sim 4796 \mathrm{~km}$ ) was not sufficient to resolve stock-related differences.

Fu's $F_{\mathrm{s}}$ departed significantly from expectations in all sampled regions. The driving force of significant departures from neutrality in our samples was the excess of singletons, an outcome that is indicative of past population expansions (Aris-Brosou and Excoffier, 1996). Pairwise mismatch distributions were unimodal for all regions, indicating relatively recent range expansions with continued gene flow between populations through time (Fig. 3) (Rogers and Harpending, 1992; Díaz-Jaimes et al., 2006). In the central North Atlantic, the low number of samples could have heavily influenced the extremely low $F$ estimation observed in the mismatch analyses $(P=0.013)$. Owing to the low numbers of samples from both the eastern Caribbean Sea and central North Atlantic, mismatch distributions should not be considered conclusive of population expansions until more samples are included into future model analyses.

Because of extensive mixing on a fishery stock level and support for a single regionally linked population across the sampled region, we suggest that a multijurisdictional and international approach to management is necessary. The most accurate landings information should be shared among all jurisdicitions where dolphinfihs are caught. However, we leave open the question of whether the eastern Caribbean Sea can be managed separately (though still internationally), and it is not clear how the central North Atlantic (i.e., Azores Islands) should be grouped as a result of a low number of samples; in future studies, more samples from this region should be collected and compared.

Our results are similar to those of Díaz-Jaimes et al. (2006), who found a single panmictic eastern Pacific population of dolphinfish that occurs within the northern portion of the Gulf of California and off Chiapas in southern mainland Mexico. The major difference between the 2 regions is the number of jurisdictions where dolphinfish are harvested. In the eastern Pacific, the geographic extent of the Díaz-Jaimes et al. (2006) study spanned only one exclusive economic zone (EEZ); in contrast, as many as 30 EEZs (Mahon, 1996) exist in the area examined in our study. Therefore, in the western central Atlantic, stock assessments will become inherently more complex because of the shared nature of the resource among many resource users. Subsequently, to effectively manage dolphinfish in the western central Atlantic, stock assessments need to incorporate the movement of dolphinfish through distant and adjacent EEZs, the timing of arrival to different EEZs, the amount landed in each location, and the demographics of this species at different scales.

\section{Acknowledgments}

This research was supported by funding through the U.S. Fish and Wildlife and Puerto Rico Department of Natural and Environmental Resources F-66.1 project to the Department of Marine Sciences, University of Puerto Rico at Mayagüez. We thank R. Chapman and the Marine Resources Division of the South Carolina Department of Natural Resources and H. Oxenford and N. Simpson of the Centre for Resource Management and Environmental Studies at the University of the West Indies for providing additional samples for use in this study. We also thank J. Hyde for providing a preliminary review on an earlier version of this manuscript. Lastly, we thank M. Botello, I. Báez, A. Alfalla, C. Whitley, M. Lugo, E. Martínez, M. Carlo, A. Santiago, and O. Espinosa for help in the field collecting samples.

\section{Literature cited}

Allendorf, F. W., N. Ryman, and F. M. Utter.

1987. Genetics and fishery-management: past, present, and future. In Population genetics and fishery management (N. Ryman and F. Utter, eds.), p. 1-20. Univ. Washington Press, Seattle, WA. 
Alvarado Bremer, J. R., J. Mejuto, J. Gómez-Márquez, F. Boán, P. Carpintero, J. M. Rodríguez, J. Viñas, T. W. Greig, and B. Ely.

2005. Hierarchical analyses of genetic variation of samples from breeding and feeding grounds confirm the genetic partitioning of northwest Atlantic and South Atlantic populations of swordfish (Xiphias gladius L.). J. Exp. Mar. Biol. Ecol. 327:167-182. Article

Alvarado Bremer, J. R., J. Mejuto, T. W. Greig, and B. Ely. 1996. Global population structure of the swordfish (Xiphias gladius L.) as revealed by analysis of the mitochondrial DNA control region. J. Exp. Mar. Biol. Ecol. 197:295-310. Article

Aris-Brosou, S., and L. Excoffier.

1996. The impact of population expansion and mutation rate heterogeneity on DNA sequence polymorphism. Mol. Biol. Evol. 13:494-504.

Begg, G. A., and J. R. Waldman.

1999. An holistic approach to fish stock identification. Fish. Res. 43:35-44. Article

Benetti, D. D., R. W. Brill, and S. A. Kraul Jr.

1995. The standard metabolic rate of dolphinfish. J. Fish. Biol. 46:987-996. Article

Bermingham, E., S. S. McCafferty, and A. P. Martin.

1997. Fish biogeography and molecular clocks: perspectives from the Panamanian isthmus. In Molecular Systematics of Fishes (T. D. Kocher and C. A. Stepien, eds.), p. 113-128. Academic Press, San Diego, CA. Article

Boustany, A. M., C. A. Reeb, and B. A. Block.

2008. Mitochondrial DNA and electronic tracking reveal population structure of Atlantic bluefin tuna (Thunnus thynnus). Mar. Biol. 156:13-24. Article

Bowen, B. W., A. Muss, L. A. Rocha, and W. S. Grant.

2006. Shallow mtDNA coalescence in Atlantic pygmy angelfishes (genus Centropyge) indicates a recent invasion from the Indian Ocean. J. Hered. 97:1-12. Article

Carlsson, J., J. R. McDowell, J. E. L. Carlsson, D. Ólafsdóttir, and J. E. Graves.

2006. Genetic heterogeneity of Atlantic bluefin tuna caught in the eastern North Atlantic Ocean south of Iceland. ICES J. Mar. Sci. 63:1111-1117.

Collette, B. B., C. Reeb, and B. A. Block.

2001. Systematics of the tunas and mackerels (Scombridae). Fish Physiol. 19:1-33.

Clement, M., D. Posada, and K. A. Crandall.

2000. TCS: a computer program to estimate gene genealogies. Mol. Ecol. 9:1657-1659. Article

Coëtlogon, G. de, C. Frankignoul, M. Bentsen, C. Delon, H. Haak, S. Masina, and A. Paradaens.

2006. Gulf Stream variability in five oceanic general circulation models. J. Phy. Oceanog. 36:2119-1235. Article

Darriba, D., G. L. Taboada, R. Doallo, and D. Posada.

2012. jModelTest 2: more models, new heuristics and parallel computing. Nat. Methods 9:772. Article

Díaz-Jaimes, P., M. Uribe-Alcocer, S. Ortega-García, and J.-D. Durand.

2006. Spatial and temporal mitochondrial DNA genetic homogeneity of dolphinfish populations (Coryphaena hippurus) in the eastern central Pacific. Fish. Res. 80:333-338. Article

Díaz-Jaimes, P., M. Uribe-Alcocer, A. Rocha-Olivares, F. J. García-de-León, P. Nortmoon, and J. D. Durand.

2010. Global phylogeography of the dolphinfish (Coryphaena hippurus): the influence of large effective population size and recent dispersal on the divergence of a marine pelagic cosmopolitan species. Mol. Phylogenet. Evol. 57:1209-1218. Article

Ditty, J. G., R. F. Shaw, C. B. Grimes, and J. S. Cope.

1994. Larval development, distribution, and abundance of common dolphin, Coryphaena hippurus, and pompano dolphin, C. equiselis (family: Coryphaenidae), in the northern Gulf of Mexico. Fish. Bull. 92:275-291.

Eldridge, M. B., and P. G. Wares.

1974. Some biological observations of billfishes taken in the eastern Pacific Ocean, 1967-1970. In Proceedings of the international billfish symposium, Pt. 2. Review and contributed papers; Kailua-Kona, HI, 9-12 August 1972 (R. S. Shomura and F. Williams, eds.), p. 89-101. NOAA Tech. Rep. NMFS SSRF-675.

Excoffier, L., and H. E. L. Lischer.

2010. Arlequin suite ver 3.5: a new series of programs to perform population genetics analyses under Linux and Windows. Mol. Ecol. Resour. 10:564-567. Article

Farrell, E. R., A. M. Boustany, P. N. Halpin, and D. L. Hammond.

2014. Dolphinfish (Coryphaena hippurus) distribution in relation to biophysical ocean conditions in the northwest Atlantic. Fish. Res. 151:177-190. Article

Fu, Y. X.

1997. Statistical tests of neutrality against population growth, hitchhiking and background selection. Genetics 147:915-925.

Garber, A. F., M. D. Tringali, and J. S. Franks.

2005. Population genetic and phylogeographic structure of wahoo, Acanthocybium solandri, from the western central Atlantic and central Pacific Oceans. Mar. Biol. 147:205-214.

Graves, J. E.

1998. Molecular insights into the population structures of cosmopolitan marine fishes. J. Hered. 89:427-437.

Graves, J. E., and A. E. Dizon.

1989. Mitochondrial DNA sequence similarity of Atlantic and Pacific albacore tuna. Can. J. Fish. Aquat. Sci. 46:870-873. Article

Graves, J. E., and J. R. McDowell.

1994. Genetic analysis of striped marlin (Tetrapturus audax) population structure in the Pacific Ocean. Can. J. Fish. Aquat. Sci. 51:1762-1768. Article

2001. A genetic perspective on the stock structures of blue marlin and white marlin in the Atlantic Ocean. Collect. Vol. Sci. Pap. ICCAT 53:180-187. [Available at website.] 2003. Stock structure of the world's istiophorid billfishes: a genetic perspective. Mar. Freshw. Res. 54:287-298. Article

Hauser, L., and G. R. Carvalho.

2008. Paradigm shifts in marine fisheries genetics: ugly hypotheses slain by beautiful facts. Fish Fish. 9:333-362. Article

Hauser, L., and R. D. Ward.

1998. Population identification in pelagic fish: the limits of molecular markers. In Advances in molecular ecology (G. R. Carvalho, ed.), p. 191-224. IOS Press, Amsterdam.

Hilborn, R., and C. J. Walters.

1992. Quantitative fisheries stock assessment: choice, dynamics, and uncertainty, 570 p. Routledge, Chapman, \& Hall, New York.

Kimura, M.

1968. Evolutionary rate at the molecular level. Nature 217:624-626. Article 
Maddison, W. P., and D. R. Maddison.

2011. Mesquite: a modular system for evolutionary analysis, version 2.75. [Available at website.]

Mahon, R.

1996. Fisheries and research for tunas and tuna-like species in the western central Atlantic: implications of the agreement for the implementation of the provisions of the United Nations convention on the law of the sea 10 December 1982 relating to the conservation and management of straddling fish stocks and highly migratory fish stocks. FAO Fish Tech. Pap. 357, 62. [Available at website.]

Mahon, R., and H. A. Oxenford.

1999. Precautionary assessment and management of dolphinfish in the Caribbean. Sci. Mar. 63:429-438. Article

McDowell, J. R., J. E. L. Carlsson, and J. E. Graves.

2007. Genetic analysis of blue marlin (Makaira nigricans) stock structure in the Atlantic Ocean. Gulf Caribb. Res. 19:75-82.

Merten, W., R. Appeldoorn, and D. Hammond.

2014a. Movements of dolphinfish (Coryphaena hippurus) along the U.S. east coast as determined through mark and recapture data. Fish. Res. 151:114-121. Article

2014b. Spatial differentiation of dolphinfish (Coryphaena hippurus) movements relative to the Bahamian archipelago. Bull. Mar. Sci. 90:849-864. Article

Oxenford, H. A.

1999. Biology of the dolphinfish (Coryphaena hippurus) in the western central Atlantic: a review. Sci. Mar. 63:277-301. Article

Oxenford, H. A., and W. Hunte.

1986. A preliminary investigation of the stock structure of the dolphin, Coryphaena hippurus, in the western central Atlantic. Fish. Bull. 84:451-460.

Palko, B. J., G. L. Beardsley, and W. J. Richards.

1982. Synopsis of the biological data on Coryphaena hippurus Linnaeus and Coryphaena equiselis Linnaeus. NOAA Tech. Rep. NMFS Circ. 443, 35 p.

Posada, D.

2008. jModelTest: phylogenetic model averaging. Mol. Biol. Evol. 25:1253-1256. Article

Reiss, H., G. Hoarau, M. Dickey-Collas, and W. J. Wolff.

2009. Genetic population structure of marine fish: mismatch between biological and fisheries management units. Fish Fish. 10:361-395. Article

Richardson, D. E.

2008. Physical and biological characteristics of billfish spawning habitat in the Straits of Florida. Ph.D. diss., 194 p. Univ. Miami, Coral Gables, FL.

Richardson, P. L.

1993. A census of eddies observed in North Atlantic SO-

FAR float data. Prog. Oceanog. 31:1-50. Article

Rivera, G. A., and R. S. Appeldoorn.

2000. Age and growth of dolphinfish, Coryphaena hippurus, off Puerto Rico. Fish. Bull. 98:345-352.

Rocha-Olivares, A., M. Bobadilla-Jiménez, S. Ortega-García, N. Saavedra-Sotelo, and J. R. Sandoval-Castillo.

2006. Mitochondrial variability of dolphinfish (Coryphaena hippurus) populations in the Pacific Ocean. Cienc. Mar. 32:569-578. [Available at website.]

Rogers, A. R., and H. Harpending.

1992. Population growth makes waves in the distribution of pairwise genetic differences. Mol. Biol. Evol. 9:552-569.

Rose, C. D., and W. W. Hassler.

1968. Age and growth of the dolphin, Coryphaena hippurus (Linnaeus), in North Carolina waters. Trans. Am. Fish. Soc. 97:271-276. Article

Salcedo-Bojorquez, S., and F. Arreguin-Sanchez.

2011. An exploratory analysis to identify reproductive strategies of billfishes. J. Fish. Aquat. Sci. 6:578-591. Article

Tamura, K., and M. Nei.

1993. Estimation of the number of nucleotide substitutions in the control region of mitochondrial DNA in humans and chimpanzees. Mol. Biol. Evol. 10:512-526.

Theisen, T. C., B. W. Bowen, W. Lanier, and J. D. Baldwin.

2008. High connectivity on a global scale in the pelagic wahoo, Acanthocybium solandri (tuna family Scombridae). Mol. Ecol. 17:4233-4247. Article

Tripp-Valdez, M. A., F. J. García de León, S. Ortega-García, D. Lluch-Cota, J. López-Martínez, and P. Cruz.

2010. Population genetic structure of dolphinfish (Coryphaena hippurus) in the Gulf of California, using microsatellite loci. Fish. Res. 105:172-177. Article

Waples, R. S., A. E. Punt, and J. M. Cope.

2008. Integrating genetic data into management of marine resources: how can we do it better? Fish Fish 9:423-449. Article

Witzell, W. N., and E. L Scott.

1990. Blue marlin, Makaira nigricans, movements in the western north Atlantic Ocean: results of a cooperative game fish tagging program, 1954-88. Mar. Fish. Rev. 52(2):12-17. 